$11-2-2021$

\title{
Learning loss among adolescent girls during the COVID-19 pandemic in rural Bangladesh
}

\author{
Sajeda Amin \\ Population Council \\ Md. Irfan Hossain \\ Population Council \\ Sigma Ainul \\ Population Council
}

Follow this and additional works at: https://knowledgecommons.popcouncil.org/departments_sbsr-pgy

Part of the Education Commons, and the Family, Life Course, and Society Commons How does access to this work benefit you? Let us know!

\section{Recommended Citation}

Amin, Sajeda, Md. Irfan Hossain, and Sigma Ainul. 2021. "Learning loss among adolescent girls during the COVID-19 pandemic in rural Bangladesh." New York: Population Council. 


\section{LEARNING LOSS AMONG ADOLESCENT GIRLS DURING THE COVID-19 PANDEMIC IN RURAL BANGLADESH}

Poor learning remains a central challenge in Bangladesh despite considerable progress in advancing schooling access and reducing gender gaps in education. The learning crisis is feared to have been exacerbated during extended school closures and limited alternative opportunities for schooling during the COVID-19 pandemic. This brief summarizes findings on learning loss among adolescent girls during the pandemic in rural Bangladesh.

\section{BACKGROUND}

\section{Girls' Education}

Bangladesh has made significant strides in promoting access to schooling for girls. While it started with very low levels of school attendance and significant gender differentials, Bangladesh was among the first countries to meet Millennium Development Goal targets in Asia by achieving gender parity in schooling. According to the Demographic and Health Surveys (DHS), both boys and girls now attain about 7 years of schooling.

However national learning assessments conducted by the Government of Bangladesh show poor literacy and numeracy skills among students - only 25 percent to 44 percent of the students in grades 5 through 8 have mastery over Bangla, English and math, and performance on these measures is especially low among poor students. ${ }^{1}$ Equally concerning is that fewer than 1 in 2 boys and barely 1 in 3 girls who completed primary education were functionally literate. Low learning levels are attributed to multiple factors, including very short school hours, a consequence of primary and secondary schools accommodating rising demands for schooling by double shifting. Indeed, the total number of school days and hours in Bangladesh are among the lowest in the world.

Finally, although schooling is offered free of tuition cost, and primary and secondary school students are offered scholarships and stipend support - especially secondary school girls who are at high risk of dropping out often due to marriage - school success still entails considerable private costs in the form of private tutoring

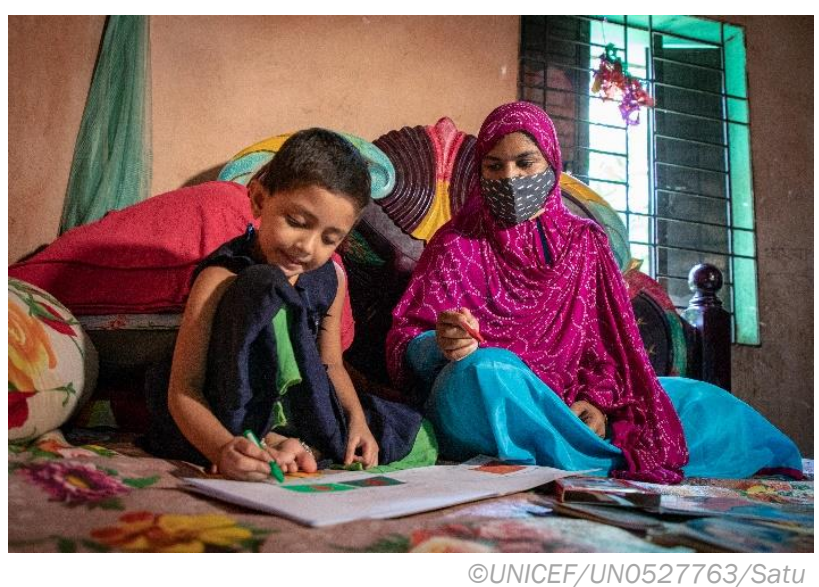

and extra coaching classes. Surveys conducted by the Population Council show that over $80 \%$ of adolescents have received private tutoring.

\section{Learning During the COVID-19 Pandemic}

In Bangladesh, schools closed in March 2020 within the first week of reported COVID-19 cases in the country and reopened in limited ways in September 2021. During the extended period of school closures, the Ministry of Education and Ministry of Primary and Mass Education implemented remote learning opportunities through state run television channels, and some schools offered virtual lessons through Facebook, which is widely available in the country. Several quantitative and qualitative studies in rural Bangladesh show however that these remote learning opportunities have differential and often limited reach. For example, in three rounds of COVID-19 follow-up surveys, Population Council studies in 2020 revealed that one third of girls or less $(21 \%, 16 \%$ and $34 \%$ in round 1 , round 2 and round 
3 , respectively) followed televised classes. ${ }^{2}$ Time spent studying declined drastically: while pre-pandemic average study time was 7-8 hours per day, this declined to 2 hours per day during COVID-19-related school closures.

"I did not participate in distance learning classes over the internet during the school closure ... I don't have a smartphone. My mother has a 'button' phone. My elder brother has a smartphone, but he uses it for his own business... Our television does not work properly, we have no satellite connection to watch BTV (the State run television channel that broadcast lessons)." IDI-6, In-school girl, age 14, Sherpur.

"When I turned on the TV, I would usually see lessons of class 5 or class 1 were being broadcast. Sometimes I could attend classes of my own grade and other times I would miss it. For the first 10-12 days, I could attend the televised classes regularly. But afterwards, I couldn't attend them on time." IDI-1

"I used to attend televised classes. But I didn't always have the routine, as classes of different subjects were broadcast on different days at different times. The English classes would span between 10 to 15 minutes. So, I couldn't understand that subject well. I could mostly understand the lessons, but I never had enough time to note down the homework in the time given." IDI-5

"We have access to internet in our home, and I had heard that online classes were being conducted, but I didn't care much about it. However, I could not attend

the online classes as I don't have a Facebook account. I have not opened an account as I'm not allowed to open an account (by my conservative family)". IDI-4

\section{DATA AND METHODS}

The data for the current assessment of learning loss/gain come from 24 comparison villages of an intervention research study. While comparison villages did not receive the intervention being tested, they would have received remote learning programs provided by the government. A baseline survey was conducted in 2018 and an endline survey was completed in July 2021 in intervention and comparison villages. All the study villages are located in rural districts of Chapainawabganj, Kushtia, and Sherpur. These districts are identified as high child marriage districts and were chosen for an

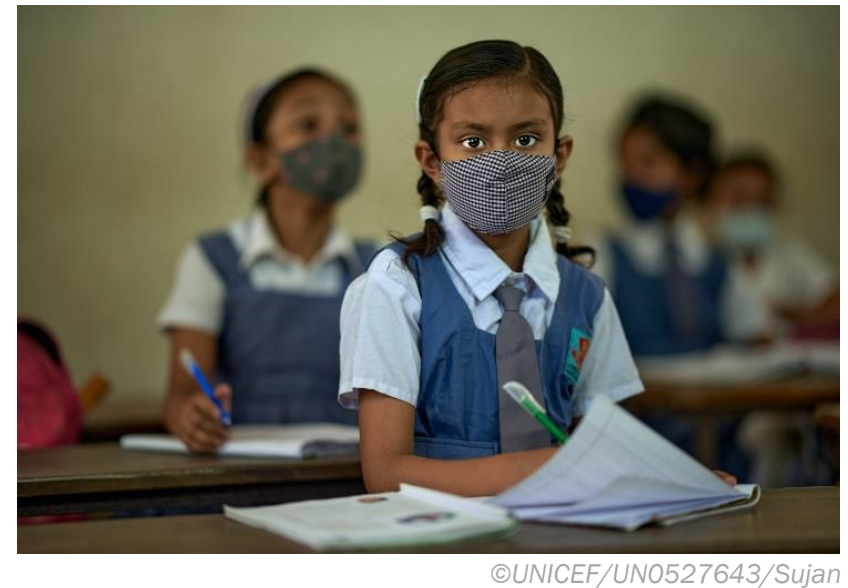

intervention study to offer life skills and remedial education for underperforming adolescent girls in grade 7 and 8 including girls who were no longer in school. The sample was drawn from a representative sample of adolescents $12-19$ residing in the study areas. The districts varied in terms of economic development-while Kushtia is well connected by roads and relatively prosperous, Chapainawabganj and Sherpur are relatively impoverished. Of the three districts, Sherpur is the closest to the urban metropolitan area of Dhaka and there is significant migration to Dhaka.

\section{Data Collection and Sample Characteristics}

The baseline and endline surveys were conducted two years apart and used a repeat cross-sectional design. Samples were drawn from household listings conducted prior to the survey which provided a representative sample of adolescents living in the study area. The listing and surveys were all collected in person and entered using mobile survey tools. Data were uploaded to a central server in real time or, if there were connectivity issues, at the end of the day. For learning assessment questions, participants were provided with a worksheet, pen and paper. Answers were entered directly into the survey instrument by the interviewer.

Mathematical competence was assessed with questions on addition, subtraction, multiplication, division, fraction manipulation and several conceptual and word problems for a total of 19 questions. Reading competencies were assessed by asking the respondent to read two Bangla and two English statements. Questions were worded in exactly the same way in the baseline and endline questionnaires with the same response categories. There was also no variation in the questions based on grade or age - all participants answered the same questions. Correct answers were converted into a composite score, with a total possible score of 22 . 


\section{RESULTS}

Figure 1 shows girls' schooling status and highest grade completed among those enrolled at baseline.

Approximately $77 \%$ of girls were in school, and about one in four girls had previously attended school but left school. While students should have completed 5 th grade by age $11,21 \%$ of those attending school had not yet completed grade 5 .

FIGURE 1. Girls' schooling status and highest grade completed (those enrolled) at baseline (\%)

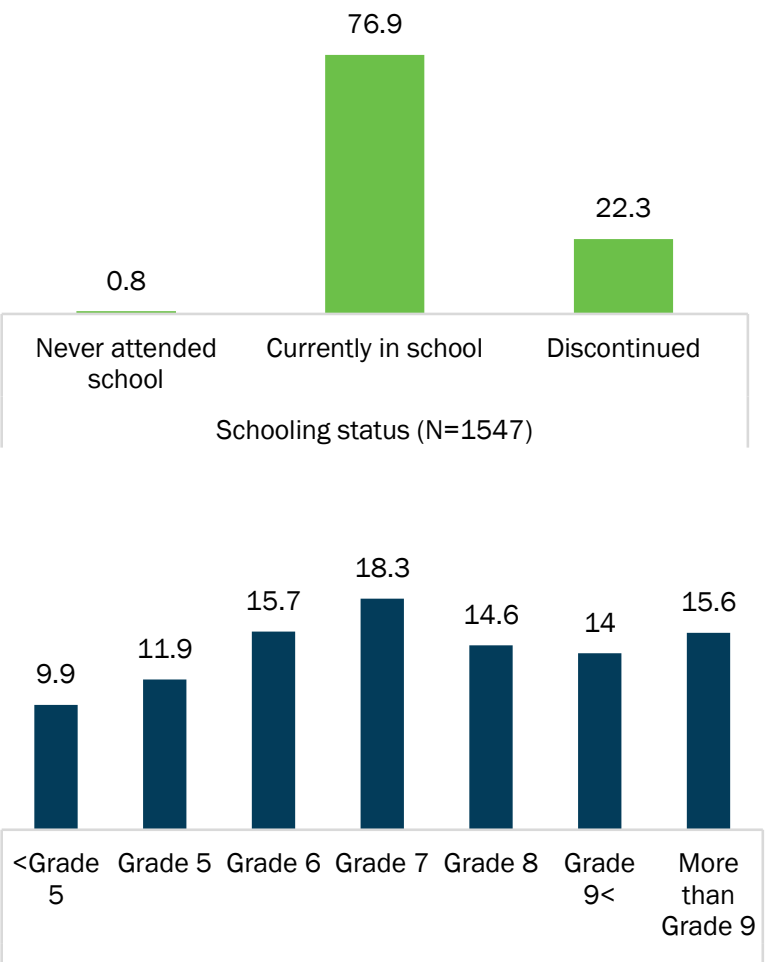

Highest grades completed for those enrolled $(\mathrm{N}=1189)$

Table 1 shows literacy and numeracy scores for girls who are enrolled from before COVID-19 (2018 baseline) and scores after one year of COVID-related school closures (2021 endline). At baseline, girls, on average, correctly answered just two-thirds (65\%) of the questions, with a median score of $70 \%$. In 2021 we find declines in mean and median literacy and numeracy skills. Girls' average score dropped $5.2 \%$ (0.79 points, not significant) and median score dropped $6.25 \%$ (1 point; $p<0.05$ ). The larger drop in the median score, as opposed to the mean, indicates that a greater proportion of girls were scoring lower than before the pandemic.
TABLE 1. Change in girl's median and mean learning scores from baseline to endline

\begin{tabular}{|l|l|l|l|l|l|}
\hline & $\begin{array}{l}\text { Baseline } \\
\text { score } \\
\mathrm{N}=1189\end{array}$ & $\begin{array}{l}\text { Endline } \\
\text { score } \\
\mathrm{N}=1191\end{array}$ & $\begin{array}{l}\text { Learning } \\
\text { loss from } \\
\text { baseline } \\
\text { to endline }\end{array}$ & $\begin{array}{l}\text { Percent } \\
\text { decline }\end{array}$ & p-value \\
\hline Median & 16.00 & 15.00 & -1.00 & $-6.25 \%$ & $0.00 * *$ \\
\hline Mean & 15.26 & 14.47 & -0.79 & $-5.18 \%$ & 0.13 \\
\hline \multicolumn{5}{|c|}{$p \leq 0.05,{ }^{*} p \leq 0.01$ for a one-tailed test }
\end{tabular}

Our data suggest that in addition to overall loss in levels of learning, the pandemic has resulted in widening learning gaps by household wealth that were significant to begin with.

Table 2 shows results from unadjusted analyses, contrasting learning scores for girls by key asset/wealth indicators (owns television, smartphone, wealth ranking and marital status) at baseline and endline. Both at baseline and at endline, girls in wealthy households, and households that own a television, had significantly higher scores. Ownership of smartphone was significantly associated with a higher score at endline. By contrast marital status did not make any significant difference to learning scores.

TABLE 2. Comparing average total scores across asset/wealth indicators within survey rounds

\begin{tabular}{|c|c|c|c|c|c|c|c|}
\hline & \multicolumn{3}{|c|}{$\begin{array}{l}\text { Baseline } \\
\text { (3) }\end{array}$} & \multicolumn{3}{|c|}{$\begin{array}{l}\text { Endline } \\
\text { (4) }\end{array}$} \\
\hline & & $\begin{array}{l}\text { Avg. } \\
\text { total } \\
\text { score }\end{array}$ & $\mathrm{N}$ & $p$-Value & $\begin{array}{l}\text { Avg. } \\
\text { total } \\
\text { score }\end{array}$ & $\mathrm{N}$ & $p$-Value \\
\hline \multirow[b]{2}{*}{ TV } & Y & 16.03 & 665 & \multirow[b]{2}{*}{$0.01 * *$} & 15.19 & 661 & \multirow[b]{2}{*}{$0.01 *$} \\
\hline & $\mathrm{N}$ & 14.28 & 524 & & 13.57 & 530 & \\
\hline \multirow{2}{*}{$\begin{array}{l}\text { Smart- } \\
\text { phone }\end{array}$} & $Y$ & 17.36 & 77 & \multirow[b]{2}{*}{0.10} & 16.00 & 127 & \multirow[b]{2}{*}{$0.04 *$} \\
\hline & $\mathrm{N}$ & 15.11 & 1112 & & 14.28 & 1064 & \\
\hline \multirow{2}{*}{$\begin{array}{l}\text { Poorest } \\
40 \% \text { in } \\
\text { wealth }\end{array}$} & $Y$ & 14.06 & 481 & \multirow[b]{2}{*}{$0.01 *$} & 12.74 & 480 & \multirow[b]{2}{*}{$0.00 * *$} \\
\hline & $\mathrm{N}$ & 16.08 & 708 & & 15.63 & 711 & \\
\hline \multirow[b]{2}{*}{ Married } & $Y$ & 16.09 & 58 & & 14.90 & 84 & \multirow[b]{2}{*}{0.64} \\
\hline & $\mathrm{N}$ & 15.22 & 1131 & 0.54 & 14.43 & 1107 & \\
\hline
\end{tabular}


TABLE 3. Comparing learning loss over time and across asset/wealth indicators

\begin{tabular}{|c|c|c|c|c|}
\hline & & $\begin{array}{l}\text { Learning loss } \\
\text { baseline to } \\
\text { endline } \\
\text { (5) }\end{array}$ & $\begin{array}{l}\text { Difference in learning } \\
\text { loss by asset /marital } \\
\text { status } \\
\text { (6) }\end{array}$ & $\begin{array}{c}\text { p- } \\
\text { Value } \\
\text { (7) }\end{array}$ \\
\hline \multirow[b]{2}{*}{ TV } & $\mathrm{Y}$ & -0.84 & \multirow[b]{2}{*}{0.13} & \multirow[b]{2}{*}{0.71} \\
\hline & $\mathrm{N}$ & -0.71 & & \\
\hline \multirow[b]{2}{*}{ Smartphone } & $\mathrm{Y}$ & -1.36 & \multirow[b]{2}{*}{0.53} & \multirow[b]{2}{*}{0.43} \\
\hline & $\mathrm{N}$ & -0.83 & & \\
\hline \multirow{2}{*}{$\begin{array}{l}\text { Poorest } 40 \% \text { in } \\
\text { wealth }\end{array}$} & $\mathrm{Y}$ & -1.32 & \multirow[b]{2}{*}{0.87} & \multirow[b]{2}{*}{$0.02 *$} \\
\hline & $\mathrm{N}$ & -0.45 & & \\
\hline \multirow[b]{2}{*}{ Married } & $\mathrm{Y}$ & -1.19 & \multirow[b]{2}{*}{0.40} & \multirow[b]{2}{*}{0.61} \\
\hline & $\mathrm{N}$ & -0.79 & & \\
\hline
\end{tabular}

Table 3 shows measures of learning loss between the two time points for girls in these categories. While learning differentials existed at baseline and endline for television ownership and poverty/wealth ranking, only poverty is associated with differentially greater learning loss (shown in columns 6 and 7). While television ownership was associated with higher learning scores (as seen in Table 2), change in scores over time among those who owned a television compared to those who did not own a television did not vary significantly. By contrast the association of learning loss with poverty was significant. While wealthier girls scored about 0.45 points lower on average at endline relative to baseline, poorer girls scored a full 1.32 points lower, translating to a loss that is three times greater than their non-poor peers.

These results hold in multi-variate analysis where girls in the two poorest quintiles (40\% of girls) have significantly lower scores than wealthier girls - after controlling for TV, smartphone, grade, and marital status (data not shown) suggesting that learning losses are driven by factors other than access to technology or marital status.

\section{TAKEAWAYS}

Analyses of learning loss data suggest there was significant learning loss during COVID. Preexisting differences in learning achievement by socioeconomic class increased. Girls in the poorest households score almost a full point lower on average relative to their wealthier counterparts, and learning loss is significantly greater among poor girls compared to wealthier girls. While owning a television or a smartphone is associated with higher scores, neither ownership of a television or smartphone prevented learning loss observed during the pandemic. Also somewhat surprisingly, being single does not confer the same kind of advantage as it once did.

In qualitative research conducted in the study area, girls expressed considerable anxiety about their ability to reenter school. They were particularly anxious about not having mastery of the material they should know, and even more concerned because they will be reentering at a higher grade due to auto-promotion. In addition, the fact that inequality in learning has increased presents additional challenges to adolescents who are the most disadvantaged. For girls in Bangladesh these anxieties are not limited to school. Child marriage remains prevalent and there is strong emerging evidence that the pandemic has led to increased risk of child marriage. ${ }^{3}$

\section{REFERENCES}

${ }^{1}$ Bangladesh Bureau of Educational Information and Statistics (BANBEIS). 2018. Bangladesh Education Statistics 2017. Dhaka, Bangladesh: BANBEIS, Ministry of Education.

2 Population Council. 2021. “Covid-19 Knowledge, Attitudes, Practices \& Needs-Responses from three rounds of data collection among adolescent girls in districts with high rates of child marriage." New York: Population Council.

3 Ainul, S., F.R. Noor, M.I. Hossain, I. Ehsan, M. Manzur, U. Rob, S. Amin. 2021. "Keeping girls in school to delay child marriage: a program evaluation report." Dhaka: Population Council.

Recommended Citation: Amin, S., M.I. Hossain, S. Ainul. 2021. "Learning loss among adolescent girls during the COVID-19 pandemic in rural Bangladesh." New York: Population Council. 